\title{
Recreational atmospheric pollution episodes: inhalable metalliferous particles from firework displays
}

\author{
Teresa Moreno ${ }^{\text {a, } *, \text { Xavier Querol a }}{ }^{\text {, Andrés Alastuey }}{ }^{\text {a }}$, Mari Cruz Minguillón b , Jorge Pey a , \\ Sergio Rodriguez ${ }^{\mathrm{c}}$, José Vicente Miró ${ }^{\mathrm{d}}$, Carles Felis ${ }^{\mathrm{d}}$, Wes Gibbons ${ }^{\mathrm{e}}$ \\ ${ }^{a}$ Earth Sciences Institute “Jaume Almera”, CSIC, Lluis Solé i Sabaris s/n, Barcelona 08028, Spain \\ ${ }^{b}$ Instituto de Tecnología Cerámica, Campus Universitario Riu Sec, 12006 Castellón, Spain \\ 'Izaña Atmospheric Observatory, INM-CSIC, La Marina 20, 38071 Sta. Cruz de Tenerife, Canary Islands, Spain \\ ${ }^{d}$ Conselleria de Territori i Habitatge, Generalitat Valenciana, C/ Francisco Cubells, 7, 46011 Valencia
} ${ }^{e} A P$ 23075, Barcelona 08080, Spain

\begin{abstract}
The use of fireworks creates an unusual and distinctive anthropogenic atmospheric pollution event. We report on aerosol samples collected during Las Fallas in Valencia, a 6-day celebration famous for its firework displays, and add comparative data on firework- and bonfirecontaminated atmospheric aerosol samples collected from elsewhere in Spain (Barcelona, L'Alcora and Borriana) and during the Guy Fawkes celebrations in London. Specific highprofile official firework events during Las Fallas, included the afternoon Mascletà and the nightly aerial displays (especially in the climactic final two days of the fiesta) and were accompanied by pollution spikes in suspended particles, $\mathrm{NO}, \mathrm{SO}_{2}$, and the creation and dispersal of an aerosol cloud enriched in a range of metallic elements. Notable metal aerosol concentration increases recorded during Las Fallas were: potassium (from 500 to $5900 \mathrm{ng} / \mathrm{m}^{3}$ ), aluminium (as $\mathrm{Al}_{2} \mathrm{O}_{3}$ : from around 600 to $2200 \mathrm{ng} / \mathrm{m}^{3}$ ), titanium (from 200 to $700 \mathrm{ng} / \mathrm{m}^{3}$ ), magnesium (from 100 to $500 \mathrm{ng} / \mathrm{m}^{3}$ ), lead (from 17 to $379 \mathrm{ng} / \mathrm{m}^{3}$ ), barium (from 39 to 322 $\mathrm{ng} / \mathrm{m}^{3}$ ), strontium (from 3 to $112 \mathrm{ng} / \mathrm{m}^{3}$ ), copper (from 12 to $71 \mathrm{ng} / \mathrm{m}^{3}$ ), and antimony (from 1 to
\end{abstract}

\footnotetext{
*Corresponding author. Phone: +34934095410, fax: +34934110012. e-mail: tmoreno@ija.csic.es
} 
$52 \mathrm{ng} / \mathrm{m}^{3}$ ). Firework-contaminated aerosols of similarly metalliferous composition were also identified at the other monitoring sites, although different sites show variations attributable to other sources such as bonfires and local industry. Unusual levels of the trace elements $\mathrm{Ba}, \mathrm{Sr}$ and (to a lesser extent) $\mathrm{Cu}$, always in proportions with Ba dominant, along with strongly enhanced $\mathrm{K}, \mathrm{Pb}$, and $\mathrm{Sb}$, are identified as being particularly characteristic of firework aerosols. Although firework-related recreational pollution episodes are transient in nature, they are highly concentrated, contribute significantly to total annual metal emissions, and are on average fine enough to be easily inhaled and a health risk to susceptible individuals.

Keywords: fireworks, aerosols, airborne metals, pollution episodes.

\section{Introduction}

Most anthropogenically-induced atmospheric pollution episodes in the urban environment are linked to hydrocarbon combustion by traffic and domestic heating, combined to a greater or lesser extent with industrial emissions and power generation depending on the location. Given the increasing recognition of the seriousness of urban air pollution levels as a cause of both short-term (e.g. Schwartz, 1996; Katsouyanni et al., 1997) and long-term (e.g. Hoek et al., 2002; Pope et al., 2004) negative human health effects, much effort is currently being put into monitoring and controlling such emissions. One of the more unusual anthropogenic activities that creates notable air pollution is the recreational use of fireworks to celebrate popular fiestas, a practice that, while common worldwide (e.g. at New Year), is more prevalent in some places than others. In Spain, for example, firework displays commonly accompany fiestas, especially along the northeastern coastal regions from Alicante to the Costa Brava, the most famous event being Las Fallas, when several days of celebration in the provinces of Alicante, Valencia and Castellón culminate in the fiesta of San José on 18-19 $9^{\text {th }}$ March. In this paper we report on the concentrations and chemistry of inhalable particles $<10 \mu \mathrm{m}$ in diameter $\left(\mathrm{PM}_{10}\right)$ collected by air sampling during Las Fallas, emphasing in particular the enhanced levels of metalliferous particles that accompany the celebrations. Our data are from one site in Valencia (PM measured 
and analysed over six consecutive days of the Las Fallas fiesta in 2005) and two in Castellón (18 $8^{\text {th }}$ March). For comparison we also present data from Barcelona during the firework fiesta of San Juan in June, and from London during the annual Guy Fawkes festivities in November.

\section{Methodology}

Particulate matter samples were collected during bonfire and firework emission episodes in four urban background stations in Spain (Barcelona, Borriana, L'Alcora and Valencia: Fig. 1) and one in the United Kingdom (London), all representing urban locations distant from specific sources and broadly representative of city-wide background concentrations. All Spanish sites registered $\mathrm{PM}_{10}$ levels, with Barcelona also measuring $\mathrm{PM}_{2.5}$, whereas in London only $\mathrm{PM}_{2.5}$ was collected. The Valencia site in Los Viveros (Royal Gardens : 39² 28' 41" N; 0 22' 06" W; 11 ma.s.l.) is part of the air quality network of the Generalitat Valenciana (Valencian Autonomous Government), and lies $1 \mathrm{~km}$ NNE of the Plaza del Ayuntamiento in the centre of the city where daily official firework events took place during Las Fallas. Total suspended particles (TSP) were measured in this station with automated instruments Beta Met One BAM1020, based on the measurement of the absorbtion coefficients of Beta radiation in a glass fibre filter before and after the collection of PM (data available from the Valencian air quality network http://www.cma.gva.es/cidam/emedio/atmosfera). Both L'Alcora (40 $04^{\circ}$ '07' $\mathrm{N} ; 00^{\circ}$ $12^{\prime} 43^{\prime \prime} \mathrm{W} ; 175$ ma.s.l.) and Borriana ( $39^{\circ} 53^{\prime} 38^{\prime \prime} \mathrm{N}$; $00^{\circ} 05^{\prime} 10^{\prime \prime} \mathrm{W} ; 20$ ma.s.l.) are also part of the Valencian air quality network. Borriana is located within the Riu Sec Valley, 4km eastern from a major ceramic area (Vila-real), from where contaminants can reach the area transported by the night breeze or the NW dominant winds. The Borriana collection site was contaminated more by local bonfires than any specific major official firework display event. The L'Alcora site is upstream within the Millars Valley, in the western side of the main ceramic area of Villa-real, and was situated very close to a major official firework display and huge bonfire. In contrast, the site in Barcelona ( $41^{\circ} 23^{\prime} 05^{\prime}$ ' $\mathrm{N}$; 02 $02^{\circ}$ '09' $\mathrm{E}$; 68 ma.s.l.) is located on the roof terrace of the Institute of Earth Sciences "Jaume Almera" (Consejo Superior de Investigaciones Científicas: CSIC). The collecting station lies 140m from the 9-lane Diagonal Avenue, one of 
the busiest highways in Barcelona, but is not close to any official firework displays or large bonfires and so measured background levels, as did the $\mathrm{PM}_{2.5}$ Guy Fawkes sample. The latter was collected in the London-Bloomsbury urban centre site (UK Automatic Urban and Rural Networks) within the north-east corner of Russell Square Gardens in central London (http://www.stanger.co.uk/siteinfo/\#).

Samples were collected every 24 hours with high volume samplers MCV-CAV with DIGITEL PM1025 inlets (Barcelona) and DIGITEL DH-80 (Borriana, L'Alcora, Valencia and London), with a flow rate of $30 \mathrm{~m}^{3} / \mathrm{h}$, using circular glass fibre filters $(15 \mathrm{~cm}$, QF20 Schleicher and Schuell). In addition $\mathrm{PM}_{10}$ (in all sites) and $\mathrm{PM}_{2.5}$ (in Barcelona) concentrations were obtained over the same collection period, using a laser spectrometer GRIMM 1108 which recorded PM concentrations on an hourly basis. PM mass concentrations obtained from the high volume samplers were compared with automatic measurements which were corrected accordingly as established by the 1999/30/CE European Directive (see http://europa.eu.int/comm/environment/air/pdf/finalwgreporten.pdf for more details about the procedure).

After sampling, filters were dried for 24 hours at room temperature, $\left(20-25^{\circ} \mathrm{C}\right.$ and $25 \%$ humidity), before being chemically analyzed to determine the concentrations of the different species (crustal components, secondary inorganic compounds, total carbon, marine aerosol and metals) following the procedure described by Querol et al. (2001), with half of each filter being bulk acid digested for the analysis of major cations and trace metals by means of ICP-AES and ICP-MS respectively. A further quarter of the sample was leached using Milli- Q-grade deionised water and the contents of major soluble anions were determined in the leachates with Ion Chromatography. $\mathrm{NH}_{4}{ }^{+}$contents in the leachates were also determined by FIA-colorimetry. Total C was determined by means of a LECO elemental analyser, a technique based on oxidising the sample instantaneously by combusting the sample with pure oxygen at approximately $1000^{\circ} \mathrm{C}$. Blank field filters were used for every stock purchased for sampling (one blank filter for each 12 filter stock). Fractions of the blank filters were analyzed in the same batches of their respective filter samples and their element concentrations subtracted from the filter samples. A few mg of the NIST $1633 \mathrm{~b}$ reference material were added to blank filters to check the precision of the data obtained. The standard deviation of blank filters was generally 
$<20 \%$. In those cases where it was higher, the element concentration in the blank showed a value always $<10 \%$ of its concentration in the sample and therefore only minimally affected the final concentration. Regarding the precision of the analyses, most of the elements showed an analytical error $<10 \%$, except for $\mathrm{P}$ and $\mathrm{K}$ which had a $15 \%$ error.

\section{Results}

Table 1 provides the ICP-AES and ICP-MS data for all sites, as well as the $\mathrm{PM}_{10}$ mass measured (excluding London). These data are discussed initially in terms of temporal variations during Las Fallas at Valencia, followed by an intercomparison of trace metals both between sites and between $\mathrm{PM}_{10}$ and $\mathrm{PM}_{2.5}$ sample fractions.

\subsection{Temporal Variations during Las Fallas}

Fireworks are utilised throughout Las Fallas although the main high-pollution events coincide with the official fiesta programme. Thus in 2005 the most spectacular smokeproducing episode during the daytime occurred in the afternoon as a consequence of $L a$ Mascletà, when huge quantities of firecrackers were ignited at 14.00. The last two days of the fiesta were marked by a notable increase in La Mascletà activity, with extra events at 11.00 and 12.00 on Friday the $18^{\text {th }}$, and at 11.00 on Saturday the $19^{\text {th }}$. With regard to official nocturnal pyrotechnic displays, these began at midnight on $15^{\text {th }}-16^{\text {th }}$ March, and gradually increased in intensity through the week. The most spectacular of the aerial firework displays took place early in the mornings of Saturday the $19^{\text {th }}$ (at 01.30: the nit de foc - the night of fire) and Sunday the $20^{\text {th }}$ (at 01.00: the ramillete de fuegos aéreos - bouquet of aerial fireworks). This final display was preceded by La Cremà, when fires are lit all over the city to mark the end of the fiesta. This sequence of events is recorded on Figure 2, which plots hourly Total Suspended Particles (TSP) levels over the six days (Valencian air quality network data, http://www.cma.gva.es/cidam/emedio/atmosfera). The figure shows the increasing concentration of pollutants in the early morning smoke plume generated in response to the five official aerial firework displays, with a notable jump in levels for the final two displays, as well 
as identifiable La Mascletà spikes around midday on both Friday the $18^{\text {th }}$ and Saturday the $19^{\text {th }}$ (midday data earlier than this are incomplete).

Throughout the six days during collection at the Valencia site there was no rain and winds showed a regular daily alternation between light $(<8 \mathrm{~km} / \mathrm{hr}$ ), humid morning offshore (north to northwest) and fresher (up to $15 \mathrm{~km} / \mathrm{hr}$ ) afternoon sea breezes directed onshore from the east to southeast. Figure 3 shows daily averaged TSP and total carbon levels initially climbing from Tuesday through to the main festivities on Friday. This peak, which was also prominently recorded in NO concentrations for that day (Valencian air quality network data, http://www.cma.gva.es/cidam/emedio/atmosfera), was followed by a temporary slight decline on the Saturday. Data for the final day of the fiesta record a return to increased levels of both $\mathrm{C}_{\text {total }}$ and TSP (Fig. 3), this time in response to the conflagration and aftermath of La Cremà during early Sunday morning. Dispersal of the enhanced levels of air pollutants during the week of Las Fallas is inhibited by afternoon inshore Mediterranean sea breezes reversing direction during the night to produce offshore-directed winds. This classical meteorological setting, in which pollutants remain trapped within an ageing air mass, took place throughout the week of Las Fallas in 2005.

Figure 3 also plots the concentrations of $\mathrm{K}, \mathrm{Ba}, \mathrm{Sr}$, and $\mathrm{Cu}$, these elements all being strong indicators of firework activity. Potassium compounds in the blackpowder (which is the propellent in fireworks), in the form of nitrate, perchlorate, or, much less commonly, chlorate, provide the main oxidiser during burning. Barium compounds can also be used as an oxidiser (as the chlorate $\mathrm{BaClO}_{3}$ and nitrate $\mathrm{Ba}\left(\mathrm{NO}_{3}\right)_{2}$ ) but are additionally valuable as stabilisers and, especially, as one of the main colouring agents. Both the carbonate $\left(\mathrm{BaCO}_{3}\right)$ and nitrate are used to create white effects or, in the presence of chlorine, bright green, a firework colour most typically associated with barium. Both strontium sulphate and nitrate can be used as oxidisers, and, along with the carbonate, impart a red colour to fireworks when combined with chlorine (they are also used to stabilise fireworks mixtures). Finally, copper compounds such as the chloride and oxide produce blue colouration, can be mixed with strontium compounds to create 
purple effects, and the chromite $\left(\mathrm{CuCr}_{2} \mathrm{O}_{4}\right)$ is used as a catalyst in rocket propellents (Lancaster et al., 1998).

With regard to those elements specifically linked to firework ignition, such as $\mathrm{K}, \mathrm{Ba}, \mathrm{Sr}$ and $\mathrm{Cu}$, these elements show a range of average values in urban sites across Spain $\left(0.3-0.5 \mu \mathrm{gK} / \mathrm{m}^{3}\right.$, 3.8-40.8 $\mathrm{ngBa} / \mathrm{m}^{3}, 3.0-9.7 \mathrm{ngSr} / \mathrm{m}^{3}$ and 7.5-81.0 $\mathrm{ngCu} / \mathrm{m}^{3}$ : MMA., 2006). In the case of the samples collected in Valencia, potassium increases in concentration through the week but then suddenly more than doubles in concentration on Friday to achieve weekend levels of around 4-6 $\mu \mathrm{g} / \mathrm{m}^{3}$ (Fig. 3). Ba, $\mathrm{Sr}$, and $\mathrm{Cu}$ all similarly increase throughout the first three days of the fiesta, and then, like potassium, suddenly double or even triple their concentration on the main fiesta day of Friday the $18^{\text {th }}$. Levels of all three elements remained highly elevated throughout the weekend in response to the continued pyrotechnic displays.

Figure 4 plots the concentrations of 10 metals/metalloids against a background range (in grey) of typical values found in urban air pollution monitoring sites across Spain (Querol et al., 2004; Moreno et al., 2006). All these metals are utilised in fireworks: in addition to the elements previously discussed ( $\mathrm{Ba}, \mathrm{Sr}, \mathrm{Cu}, \mathrm{K}$ and $\mathrm{Cr}$ ), $\mathrm{Ti}$ and $\mathrm{Sb}$ are used to provide silvery and glitter effects, $\mathrm{Pb}$ can be used as a red colourant and (in the form of lead tetraoxide) to produce crackling microstars, Ca compounds such as the chloride and sulphate provide an orange flame, $\mathrm{Mg}$ burns a bright electric white (and is a useful fuel) and also occurs as the alloy magnalium (50:50 MgAl) used for sparks and crackling stars, with $\mathrm{Al}$ also being used alone as a common constituent for fuel, sparks and glitter effects (Lancaster et al., 1998). It is immediately obvious from Figure 4 that all of these metals show lower concentrations during the initial days of the fiesta, when compared to the main weekend festivities from Friday to early Sunday morning. The metals that particularly stand out as present in concentrations far higher than average are $\mathrm{Pb}, \mathrm{Ba}, \mathrm{Sb}, \mathrm{Sr}$, and $\mathrm{K}$.

\subsection{Comparing sites and $P M_{10 / 2.5}$ ratios}

The firework-contaminated atmospheric aerosol burden created during Las Fallas in Valencia shows several similarities with those collected during another San José celebration 
(Friday $18^{\text {th }}$ March 2003) at the two sites of L'Alcora and Borriana in Castellón (Table 1). Of the six elements highlighted in the previous paragraph, all three sites record similar concentrations of $\mathrm{Sr}$ and $\mathrm{Ba}$ (as well as $\mathrm{Cu}$ in Borriana: there are no data for L'Alcora).The L'Alcora sample is anomalously enriched in $\mathrm{K}$, which we attribute to its proximity to a major bonfire (which also explains the high $\mathrm{PM}_{10}$ level). Borriana shows less of a "firework" signature (lower $\mathrm{Ba}$ and $\mathrm{Sr}$ ), but is unusually enriched in $\mathrm{Pb}, \mathrm{Al}$, $\mathrm{As}$ and $\mathrm{Se}$, which may be due to the effect of contamination by local industry. Although such superimposed effects will act to obscure the chemical signature emanating from firework ignition, our data suggest that the three trace elements most likely to offer indicators of firework activity are $\mathrm{Ba}, \mathrm{Sr}$ and, to a lesser extent, $\mathrm{Cu}$, all common firework colouring components. Figure 5 provides a 3-component diagram for these elements, based on the chromacity diagram introduced in the 1930's by the CIE (Commission Internationale de l'Eclairage), and used by pyrotechnians to define variations in firework colour (Berns, 2000). The figure illustrates how our firework-contaminated aerosol samples (excluding L'Alcora for lack of $\mathrm{Cu}$ analysis) are all enriched in barium relative to the other two components, with the Valencia and Borriana samples clustering particlarly closely. The most Sr-rich samples are those from the two last night aerial firework displays during Las Fallas, especially the climactic "bouquet of aerial fireworks" which, although not witnessed by the authors, is predicted to have made the greatest use of red colourants.

The data presented on Figure 6 compare concentrations for $\mathrm{C}_{\text {total }}, \mathrm{Ti}, \mathrm{Ba}, \mathrm{Sr}$ and $\mathrm{Cu}$. Most data for $\mathrm{Ba}, \mathrm{Sr}$ and $\mathrm{Cu}$ lie within (or very close to) the range provided by the two $\mathrm{PM}_{2.5}$ samples (dashed lines), as is also the case for $\mathrm{C}_{\text {total }}$ concentrations: urban carbon particles typically show a high $\mathrm{PM}_{2.5 / 10}$ ratio due to the abundance of traffic-related PM (such as diesel), enhanced in our samples by the fine carbonaceous combustion products of firework displays. This figure also again emphasises the extreme levels of enrichment in $\mathrm{Ba}$ and $\mathrm{Sr}$ of all samples compared with the normal urban range in Spain: a clear fireworks signal. $\mathrm{Cu}$ also shows an enriched signal in our samples, albeit less extreme than $\mathrm{Ba}$ and $\mathrm{Sr}$. Ti is added for comparison because, although this element is used to some extent in fireworks, the enrichment in our samples is less extreme and the $\mathrm{PM}_{2.5 / 10}$ ratio much lower, due the fact that $\mathrm{Ti}$ is a common minor component of 
minerals derived from rocks and soils (e.g. clays and feldspars). The additional firework-related component of this element will be small compared to the normal background concentration of this element which derives from both natural and anthropogenic (e.g. industry at Borriana) sources.

\section{Discussion and Conclusions}

Although there have been only a relatively limited number of other studies on atmospheric emissions emanating from fireworks, it is clear that such emissions have their own distinctive signature (Colbeck and Chung, 1996; Liu et al., 1997; Dutcher et al., 1999; Perry, 1999; Wehner et al., 2000; Kulshretha et al., 2004; Drewnick et al., 2006). During firework pollution episodes there is a transient and commonly spectacular increase in PM mass, accompanied by a prominent and equally short-lived peak in NO emissions (this was particularly prominent in the early morning data from 18-19 March during Las Fallas, Valencian air quality network data, http://www.cma.gva.es/cidam/emedio/atmosfera), this gas being a useful tracer for high temperature combustion (Wehner et al., 2000). There is an accompanying sudden rise in gases such as $\mathrm{SO}_{2}$ and metal particles, especially potassium derived from the combustion of nitrate and perchlorate (e.g. Dutcher et al., 1999), and associated bonfires. The study by Liu et al. (1997) emphasised the metalliferous, strongly inorganic nature of firework aerosols, and the fact that average particle sizes are small (around $1.2 \mu \mathrm{m}$ ). This latter study (like that of Perry, 1999) noted the likely presence of a range of metals including $\mathrm{Ba}, \mathrm{Pb}, \mathrm{Mg}, \mathrm{Al}, \mathrm{K}, \mathrm{Sr}$ and $\mathrm{Cu}$ in atmospheric firework PM, observations repeated in our data from Las Fallas as the celebrations progressed. Kulshretha et al. (2004) recorded similarly elevated metal aerosol concentrations during the Dwali festival in India during November 2002, another huge firework event lasting several days.

The contribution of metal aerosols to the atmosphere during recreational anthropogenic pollution episodes linked to fireworks is not trivial. In a report for the UK Department of Environment, Food and Rural Affairs (DEFRA), Passant (2003) has estimated that during 2002 in the UK around 73 tonnes of magnesium, 65 tonnes of $\mathrm{Ba}, 10$ tonnes of $\mathrm{Sr}, 5$ tonnes of $\mathrm{Ti}$ and 
3 tonnes of $\mathrm{Cu}$ were released annually by fireworks and other explosives. To put these figures into perspective, Passant (2003) noted that in the case of $\mathrm{Cu}$ and $\mathrm{Mg}$, this represented $6 \%$ and 7.6\% respectively of total UK emissions for these elements in 2000 (\% figures for other elements not available). Furthermore, given that firework-related recreational pollution episodes are highly transient, much of this metal burden will be emitted during a few hours in the year, and will be carried airborne in initially dense clouds of extremely fine, easily deeply inhalable particles.

Such pollutant releases, combined with enhanced emission of gases such as $\mathrm{SO}_{2}$ and accompanied by bonfire combustion products, have inevitably raised questions of possible negative short- and long-term health effects on humans exposed to dense, fireworkcontaminated pollution plumes (e.g. Ravindra et al., 2003). The short-term threat posed to susceptible individuals has already to some extent been documented and centres more on the effects of increased particle mass on respiration than on their chemical composition. An early cohort study during New Year firework events in Honolulu detected a measurable short term effect on susceptible individuals such as those with chronic respiratory disease (Smith and Dinh, 1975). More recently, and within the context of concerns over the marked increase of asthma in society, Becker et al. (2000) documented severe (including fatal) attacks in asthmatic children triggered by exposure to firework air pollution episodes. Particles fine enough to be inhaled into the deep lung environment are held responsible for the majority of both short- and long-term negative health effects associated with PM inhalation (Laden et al., 2000; Pope et al., 2002, 2004; Schwartz and Neas, 2000), and the bioreactivity of fine metal aerosols is of particular concern (Schaumann et al., 2004; Kunzli et al., 2006).

To conclude, this paper is designed as a contribution towards understanding the distinctive and unusual chemistry of the anthropogenic aerosol burden created by firework displays. We confirm that particles created by firework combustion will have a high $\mathrm{PM}_{2.5 / 10}$ ratio and, in addition to abundant potassium (the dominant metal component of the firework propellent), will contain a complex mixture of different trace metals, some of which will be present in concentrations far above their normal ranges. The most notable increases in trace metals in our 
study involve barium, strontium, lead and antimony, with copper, magnesium, aluminium and titanium showing lesser, but still large, increases. Transient spikes in firework metal aerosol concentrations will be accompanied by prominent peaks in $\mathrm{SO}_{2}$, $\mathrm{NO}$ and $\mathrm{PM}$ (especially $\mathrm{PM}_{2.5}$ ) emissions. Such emissions have been proven to be capable of inducing short term negative health effects such as asthmatic attacks in susceptible individuals. For this latter reason alone there is a case for promoting greater awareness of the undesirability of breathing firework and bonfire smoke, especially as any long-term health effects arising from transient exposures to very high levels of such contaminants remain unknown. Recognition of the concentrated and metalliferous nature of firework-induced air pollution generates the desire to create, as Ravindra et al. (2003) have commented, a strong public opinion to celebrate festivals like Diwali, New Year etc, in an environmentally friendly manner.

\section{Acknowledgements}

The authors are indebted to the Direcció General de Qualitat Ambiental, Conselleria de Territori i Habitatge (Generalitat Valenciana) for their collaboration and the data supplied (http://www.cma.gva.es/cidam/emedio/atmosfera/). Rita Van Dingenen, Jean-Philippe Putaud (Joint Research Centre, Institute for Environment and Sustainability, Ispra, Italy) and Roy M. Harrison (University of Birmingham, UK) are also thanked for their help when collecting and analysing the London sample. This study was supported by a research project from the Plan Nacional de I+D from the Spanish Ministry of Education and Science (CGL2004-05984_C0702/CLI, REN2001-0659-C03-03).

\section{References}

Becker, J.M., Iskandrian, S., Conkling, J., 2000. Fatal and near-fatal asthma in children exposed to fireworks. Annals of Allergy, Asthma and Immunology 85, 512-513.

Berns, R., 2000. Billmeyer and Saltzman's Principles of Colour Technology, third edition, John Wiley \& sons, INC, 2000. 
Colbeck, I., Chung, M-C., 1996. Ambient aerosol concentrations at a site in SE England during bonfire night 1995. Journal of Aerosol Science 27, 449-450.

Hoek, G., Brunekreef, B., Goldbohm, S. Fischer, P., van den Brandt, PA., 2002. The association between mortality and indicators of traffic-related air pollution in a Dutch cohort study. Lancet 360, 1203-1209.

Drewnick, F., Hings, S.S., Curtius, J, Eerdekens, G., Williams, J., 2006. Measurement of fine particulate and gas-phase species during the New Year's fireworks in 2005 in Mainz, Germany. Atmospheric Environment 40, 4316-4327.

Dutcher, D.D., Perry, K.D., Cahill, T.A, Copeland, S.A., 1999. Effects of indoor pyrotechnic displays on the air quality in the Houston Astrodome, Journal of the Air and Waste Management Association 49, 156-160.

Katsouyanni, K., Touloumi, G., Spix, C., Schwartz, J., Balducci, F., Medina, S. et al., 1997. Short-term effects of ambient sulphur dioxide and particulate matter on mortality in 12 European cities: results from time series data from the APHEA project. Air Pollution and Health: a European Approach. BMJ 314, 1658-63.

Kulshrestha, U.C., Nageswara Rao, T., Azhaguvel, S., Kulshrestha, M.J., 2004. Emissions and accumulation of metals in the atmosphere due to crackers and sparklers during Diwali festival in India. Atmospheric Environment 38, 4421-4425.

Kunzli N, Mudway IS, Gotschi T, Shi T, Kelly FJ, Cook S, Burney P, Forsberg B, Gauderman JW, Hazenkamp ME, Heinrich J, Jarvis D, Norback D, Payo-Losa F, Poli A, Sunyer J, Borm PJ., 2006. Comparison of oxidative properties, light absorbance, total and elemental mass concentration of ambient $\mathrm{PM}_{2.5}$ collected at 20 European sites. Environ Health Perspect 14(5), 684-90.

Laden, F., Neas, L., Dockery, D., Schwartz, J., 2000. Association of fine particulate matter from different sources with daily mortality in six U.S. cities. Environmental Health Perspectives $108,941-947$.

Lancaster, R., Butler, R., Lancaster, J., Shimizu, T. and Smith, T., 1998. Fireworks: Principles and Practice. New York: Chemical Publishing Company, 1998. 
Liu, D-Y, Rutherford, D., Kinsey, M., Prather, K.A., 1997. Real-time monitoring of pyrotechnically derived aerosol particles in the troposphere. Analytical Chemistry 69, 18081814.

Moreno, T., Querol X, Alastuey A, Viana, M, Salvador, P, Sánchez de la Campa, A., Artiñano, B., De la Rosa, J, Gibbons, W., 2006. Variations in atmospheric PM trace metal content in Spanish towns: Illustrating the chemical complexity of the inorganic urban aerosol cocktail Atmospheric Environment (in press).

Passant, N., 2003. Emissions factors programme task 1: Summary of simple desk studies. AEAT/ENV/R/1421. Appendix 1: Fireworks briefing note. Department of Environment, Food and Rural Affairs, U.K.

Perry, K.D., 1999.Effects of outdoor pyrotechnic displays on the regional air quality of western Washington State. Journal of the Air and Waste Management Association 49, 146-155.

Pope, C., Burnet, R., Thun, M., et al., 2002. Lung cancer, cardiopulmonary mortality, and long term exposure to fine particulate air pollution. JAMA 287, 1132-1141.

Pope, CA, Burnett, RT, Thurston, GD, et al., 2004. Cardiovascular mortality and long-term exposure to particulate air pollution. Circulation 109, 71-77

Querol, X., Alastuey, A., Rodríguez, S., Plana, F., Ruiz, C.R., Cots, N., Massagué, G., Puig, O., 2001. PM10 and PM2.5 source apportionment in the Barcelona Metropolitan Area, Catalonia, Spain. Atmospheric Environment 35-36, 6407-6419.

Querol, X., Alastuey, A., Viana, M.M., Rodríguez, S., Artiñano, B., Salvador, P., Garcia Do Santos, S., Fernández Patier, R., Ruiz, C., de la Rosa, J., Sánchez de la Campa, A., Menéndez, M., Gil, J.I., 2004. Speciation and origin of PM10 and PM2.5 in Spain. Journal of Aerosol Sciences 35, 1151-1172.

MMA, 2006. Niveles y composición de PM10 y PM2.5 y contaminación atmosférica por material particulado y metales en España. 2003-2006. (in press)

Ravindra, K., Mor, S., Kaushik, C. P., 2003. Short-term variation in air quality associated with firework events: A case study. Journal of Environmental Monitoring 5, 260-264. 
Schaumann, F., Born, P., Herbrich, A., Knoch, J., Pitz, M., Schins, R., Luettig, B., Hohlfeld, J., Heinrich, J., Krug, N., 2004. Metal-rich ambient particles (Particulate matter2.5) cause airway inflammation in healthy subjects. American Journal of Respiratory and Critical care Medicine 170, 898-903.

Schwartz, J., 1996. Air pollution and hospital admissions for respiratory disease. Epidemiology $7,20-8$.

Schwartz, J, Neas, LM., 2000. Fine particles are more strongly associated than coarse particles with acute respiratory health effects in schoolchildren. Epidemiology 11, 6-10.

Smith, R. M., Dinh, V-D., 1975. Changes in forced expiratory flow due to air pollution from fireworks. Environmental Research 9, 321-331.

Wehner, B., Wiedensohler, A., Heintzenberg, J., 2000. Submicrometer aerosol size distributions and mass concentration of the millenium fireworks 2000 in Leipzig, Germany. Journal of Aerosol Science 31, 1489-1493. 


\section{Figure Captions}

Figure 1: Location map for sampling localities in NE Spain.

Figure 2: Concentrations of total suspended particles (TSP) hourly measured during Las Fallas celebrations in March 2005 in Los Viveros collecting site (see methodology and Valencian air quality network data, http://www.cma.gva.es/cidam/emedio/atmosfera, for location). The thick grey line traces the progressive increase in early morning air pollution following the five nightly aerial pyrotechnic displays (positioned by the dashed line arrows). The afternoon Mascletà events also clearly influence TSP levels during the $18^{\text {th }}$ and $19^{\text {th }}$, as do the bonfires ignited during the Cremà on the last night.

Figure 3: Increasing atmospheric levels of daily automatically measured total suspended particles (TSP, Valencian air quality network data, http://www.cma.gva.es/cidam/emedio/atmosfera), and chemically analysed total Carbon, K, Ba, Sr and Cu during Las Fallas festivities in March 2005.

Figure 4: Increasing levels of metals during Las Fallas $2005\left(15^{\text {th }}-20^{\text {th }}\right.$ March $)$. The grey shaded area represents the range of typical urban concentrations for each element in $\mathrm{PM}_{10}$ samples collected from 21 Spanish towns and cities (Querol et al., 2004). Note the higher concentrations of all metals towards the end of the celebrations, and the unusually elevated levels of $\mathrm{K}, \mathrm{Pb}, \mathrm{Ba}$, $\mathrm{Sb}$ and $\mathrm{Sr}$.

Figure 5: Three-component $\mathrm{Ba}-\mathrm{Cu}-\mathrm{Sr}\left(\mathrm{ng} / \mathrm{m}^{3}\right)$ triangular diagram based on the chromacity diagram introduced in the 1930's by the CIE (Commission Internationale de l'Eclairage), and used by pyrotechnians to define variations in firework colour (Berns, 2000). See text for discussion. 
Figure 6: Concentrations of $\mathrm{C}_{\text {total }}, \mathrm{Ti}, \mathrm{Ba}, \mathrm{Sr}$ and $\mathrm{Cu}$ at all sites (see text for discussion). 


\section{Table caption}

Table 1. Selected major $\left(\mu \mathrm{g} / \mathrm{m}^{3}\right)$ and trace element $\left(\mathrm{ng} / \mathrm{m}^{3}\right)$ daily concentrations in all sites analysed with ICP-AES and ICP-MS respectively. 


\begin{tabular}{|c|c|c|c|c|c|c|c|c|c|c|c|}
\hline \multirow[b]{2}{*}{ Date } & \multirow{2}{*}{$\begin{array}{l}\begin{array}{c}\text { LAlcora } \\
\text { (2003) }\end{array} \\
18 / 03\end{array}$} & \multirow{2}{*}{$\begin{array}{l}\begin{array}{c}\text { Borriana } \\
\text { (2003) }\end{array} \\
18 / 03\end{array}$} & \multicolumn{6}{|c|}{$\begin{array}{c}\text { Valencia } \\
(2005)\end{array}$} & \multicolumn{2}{|c|}{$\begin{array}{l}\text { Barcelona } \\
\text { (2005) }\end{array}$} & \multirow{2}{*}{$\begin{array}{c}\begin{array}{c}\text { London } \\
\text { (2004) }\end{array} \\
05 / 11\end{array}$} \\
\hline & & & $15 / 03$ & $16 / 03$ & $17 / 03$ & $\begin{array}{l}18 / 03 \\
\end{array}$ & $19 / 03$ & $20 / 03$ & $23 / 06$ & $23 / 06$ & \\
\hline$\mu \mathrm{g} / \mathrm{m}^{3}$ & $\mathrm{PM}_{10}$ & $\mathrm{PM}_{10}$ & $\mathrm{PM}_{10}$ & $\mathrm{PM}_{10}$ & $\mathrm{PM}_{10}$ & $\mathrm{PM}_{10}$ & $\mathrm{PM}_{10}$ & $\mathrm{PM}_{10}$ & $\mathrm{PM}_{10}$ & $\mathrm{PM}_{2.5}$ & $\mathrm{PM}_{2.5}$ \\
\hline PM & 93 & 67 & 34 & 37 & 42 & 79 & 46 & 37 & 38 & 26 & -- \\
\hline Ctotal & 6.3 & 8.3 & 5.1 & 6.1 & 7.2 & 12.3 & 7.7 & 10.8 & 7.0 & 5.7 & 13.1 \\
\hline $\mathrm{OM}+\mathrm{EC}$ & 6.5 & 9.1 & 5.9 & 7.2 & 8.4 & 14.2 & 8.4 & 12.4 & 8.7 & 7.9 & 54.0 \\
\hline $\mathrm{CO}_{3}{ }^{2-}$ & 4.2 & 3.8 & 0.9 & 0.6 & 0.8 & 2.7 & 3.3 & 2.5 & 5.0 & 1.2 & 52.3 \\
\hline $\mathrm{Al}_{2} \mathrm{O}_{3}$ & 2.4 & 7.9 & 0.7 & 0.6 & 0.5 & 1.5 & 2.2 & 1.4 & 1.9 & 0.7 & -- \\
\hline $\mathrm{Ca}$ & 2.0 & 1.7 & 0.4 & 0.2 & 0.3 & 1.2 & 1.3 & 0.9 & 2.7 & 0.6 & 0.1 \\
\hline K & 28.1 & 7.8 & 0.5 & 1.0 & 1.5 & 3.8 & 5.9 & 4.0 & 1.3 & 0.9 & 0.1 \\
\hline $\mathrm{Na}$ & 0.2 & 0.7 & 0.3 & 0.3 & 0.1 & 0.2 & 0.2 & 0.3 & 0.7 & 0.2 & -- \\
\hline $\mathrm{Mg}$ & 0.5 & 0.5 & 0.1 & 0.1 & 0.1 & 0.3 & 0.5 & 0.5 & 0.4 & 0.1 & 2.2 \\
\hline $\mathrm{Fe}$ & 0.7 & 0.8 & 0.3 & 0.2 & 0.2 & 0.4 & 0.5 & 0.3 & 0.8 & 0.2 & 0.1 \\
\hline $\mathrm{Ti}$ & 0.08 & 0.12 & 0.02 & 0.02 & 0.02 & 0.04 & 0.07 & 0.03 & 0.05 & 0.02 & 0.04 \\
\hline$P$ & 0.03 & 0.03 & 0.05 & 0.05 & 0.02 & 0.05 & 0.07 & 0.06 & 0.03 & 0.01 & -- \\
\hline $\mathrm{SO}_{4}{ }^{2-}$ & 27.9 & 8.6 & 6.9 & 8.4 & 7.5 & 7.5 & 7.8 & 8.8 & 4.2 & 3.3 & 3.1 \\
\hline $\begin{array}{l}\mathrm{NH}_{4}^{+} \\
\mathrm{ng} / \mathrm{m}^{3}\end{array}$ & -- & 1.6 & 3.5 & 5.1 & 4.0 & 2.0 & 0.6 & 1.8 & 0.5 & 0.7 & 0.5 \\
\hline $\mathrm{Li}$ & 1.8 & 1.5 & 0.3 & 0.3 & 0.2 & 0.4 & 0.5 & 0.3 & 1.2 & 0.2 & -- \\
\hline V & 3 & 4 & 10 & 9 & 11 & 12 & 12 & 12 & 35 & 3 & 4 \\
\hline $\mathrm{Cr}$ & 10.0 & 10.0 & 0.4 & 0.3 & 1.0 & 2.6 & 2.4 & 1.4 & 8.7 & 1.8 & 0.1 \\
\hline Co & 1.1 & 1.0 & 0.3 & 0.3 & 0.5 & 0.4 & 0.3 & 0.3 & 0.5 & 0.1 & 3.5 \\
\hline $\mathrm{Ni}$ & 2.0 & 3.0 & 3.1 & 2.7 & 3.9 & 3.1 & 2.4 & 3.2 & 11.0 & 1.3 & 0.1 \\
\hline $\mathrm{Cu}$ & -- & 49 & 12 & 20 & 31 & 61 & 57 & 71 & 77 & 35 & 122 \\
\hline $\mathrm{Zn}$ & 380 & 1298 & 101 & 107 & 52 & 77 & 36 & 39 & 114 & 53 & 56 \\
\hline As & 10.0 & 77.0 & 0.8 & 1.8 & 1.9 & 1.6 & 1.0 & 2.0 & 2.04 & 0.7 & 0.1 \\
\hline Se & -- & 10 & -- & -- & 0.2 & 0.3 & 0.2 & 0.5 & 1.4 & 0.5 & 0.4 \\
\hline $\mathrm{Rb}$ & 6 & 8 & 0.7 & 0.8 & 0.8 & 1.5 & 1.7 & 1.3 & 2.6 & 0.6 & 0.2 \\
\hline $\mathrm{Sr}$ & 45 & 16 & 3 & 7 & 9 & 31 & 51 & 112 & 13 & 12 & 43 \\
\hline $\mathrm{Cd}$ & 1 & 5.7 & 0.3 & 0.3 & 0.6 & 0.6 & 0.4 & 0.5 & 0.4 & 0.3 & 2.4 \\
\hline Sn & 1 & 3 & 2 & 3 & 12 & 10 & 14 & 9 & 14 & 4 & 4 \\
\hline $\mathrm{Sb}$ & 1 & -- & 1 & 2 & 33 & 27 & 52 & 45 & 9 & 3 & 4 \\
\hline $\mathrm{Ba}$ & 248 & 126 & 39 & 54 & 78 & 236 & 283 & 322 & 89 & 65 & 224 \\
\hline La & 0.6 & 1.0 & 0.4 & 0.3 & 0.4 & 0.5 & 0.6 & 0.4 & 0.8 & 0.1 & -- \\
\hline $\mathrm{Ce}$ & 0.9 & 4.8 & 0.9 & 0.8 & 1.0 & 1.3 & 1.6 & 0.9 & 1.9 & 0.3 & 0.1 \\
\hline $\mathrm{Pb}$ & 206 & 1507 & 17 & 42 & 289 & 247 & 379 & 109 & 52 & 44 & 208 \\
\hline
\end{tabular}

Table 1 


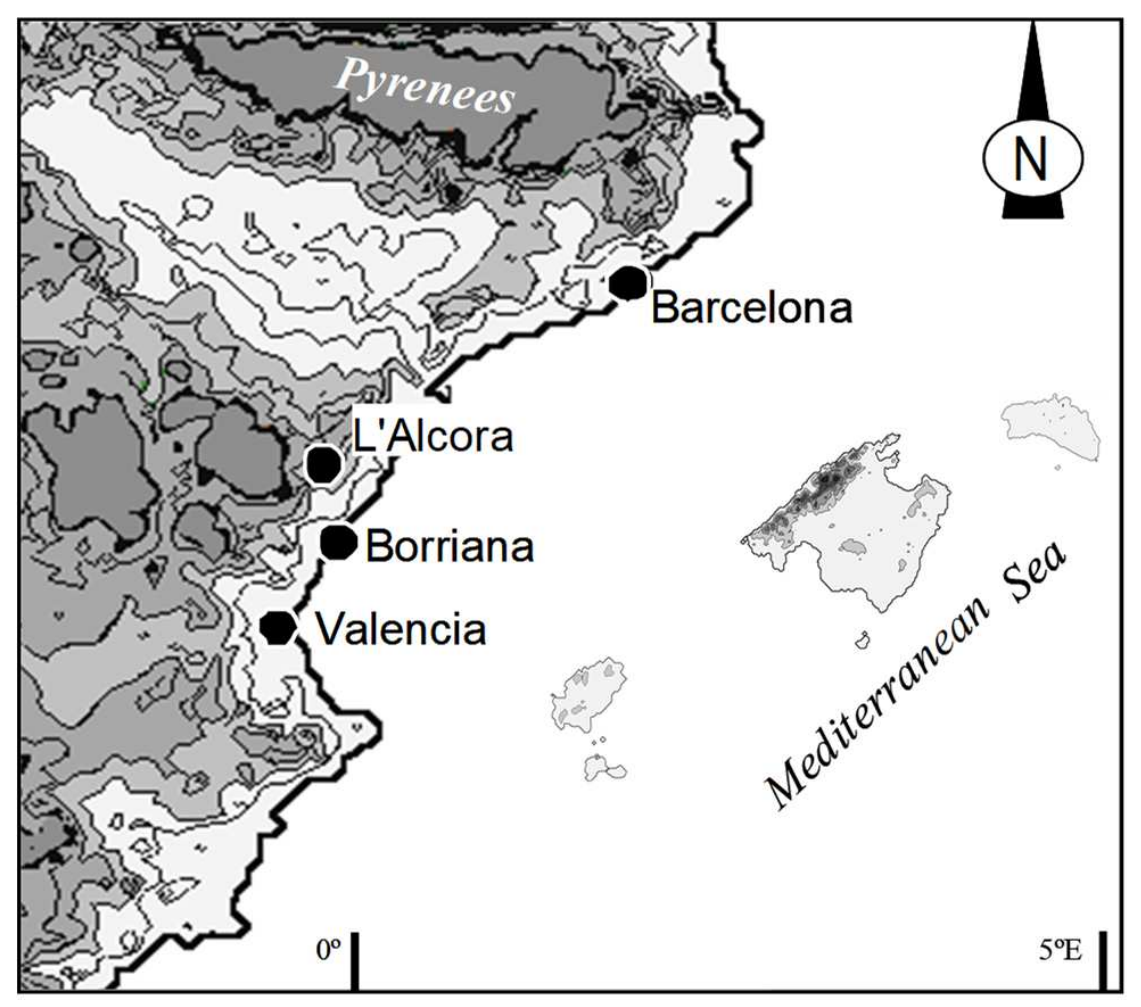

Fig 1 


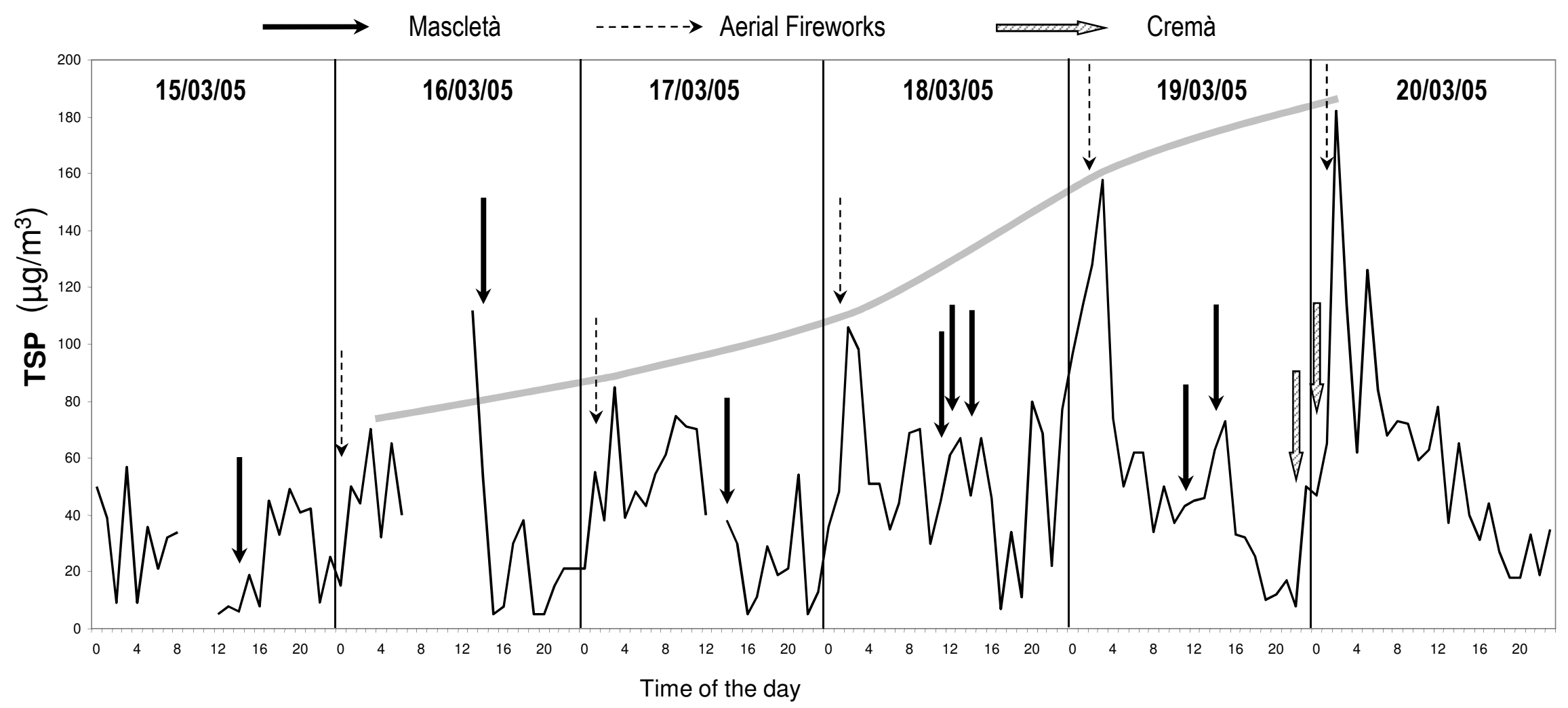

Fig 2 


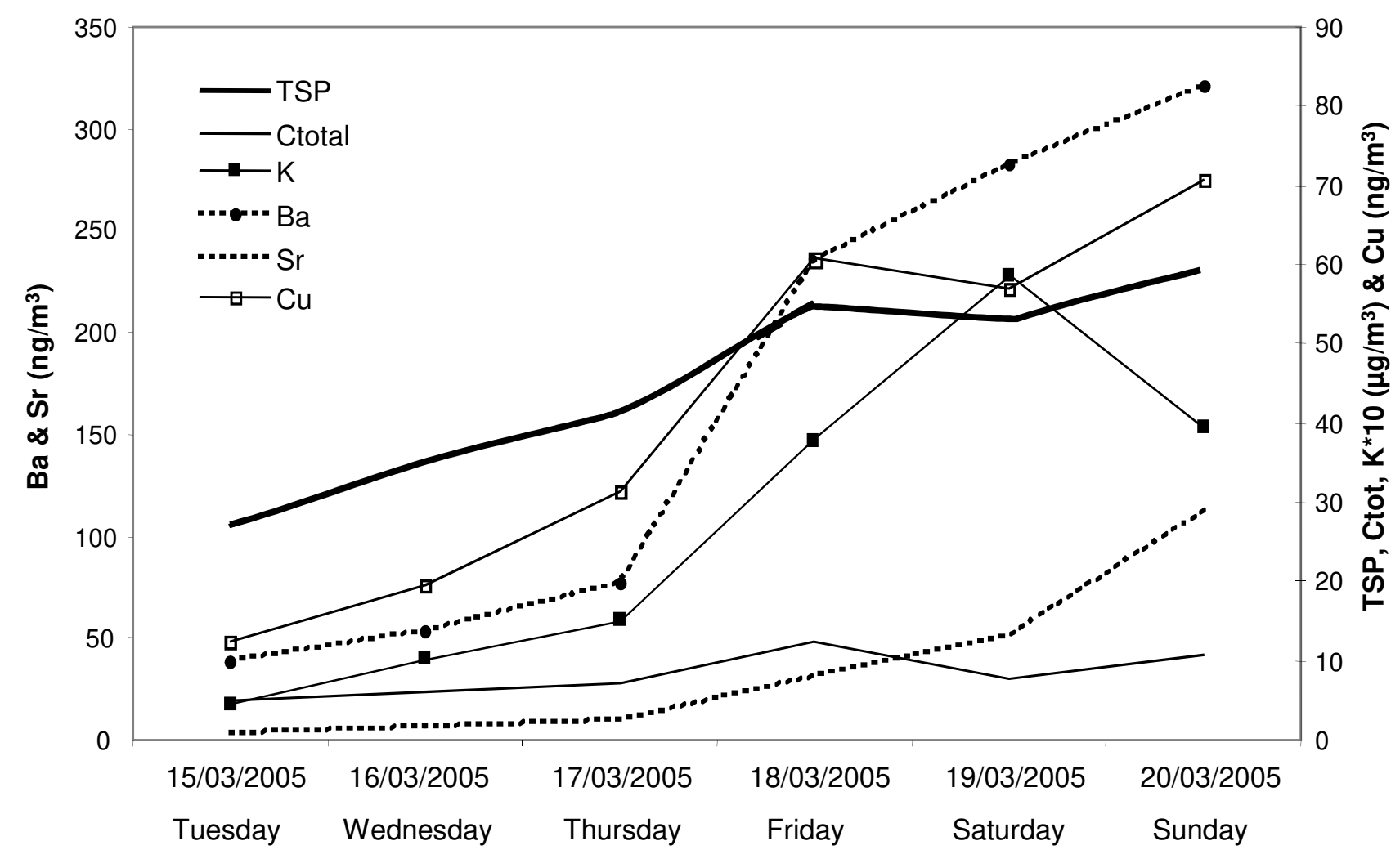

Fig 3 


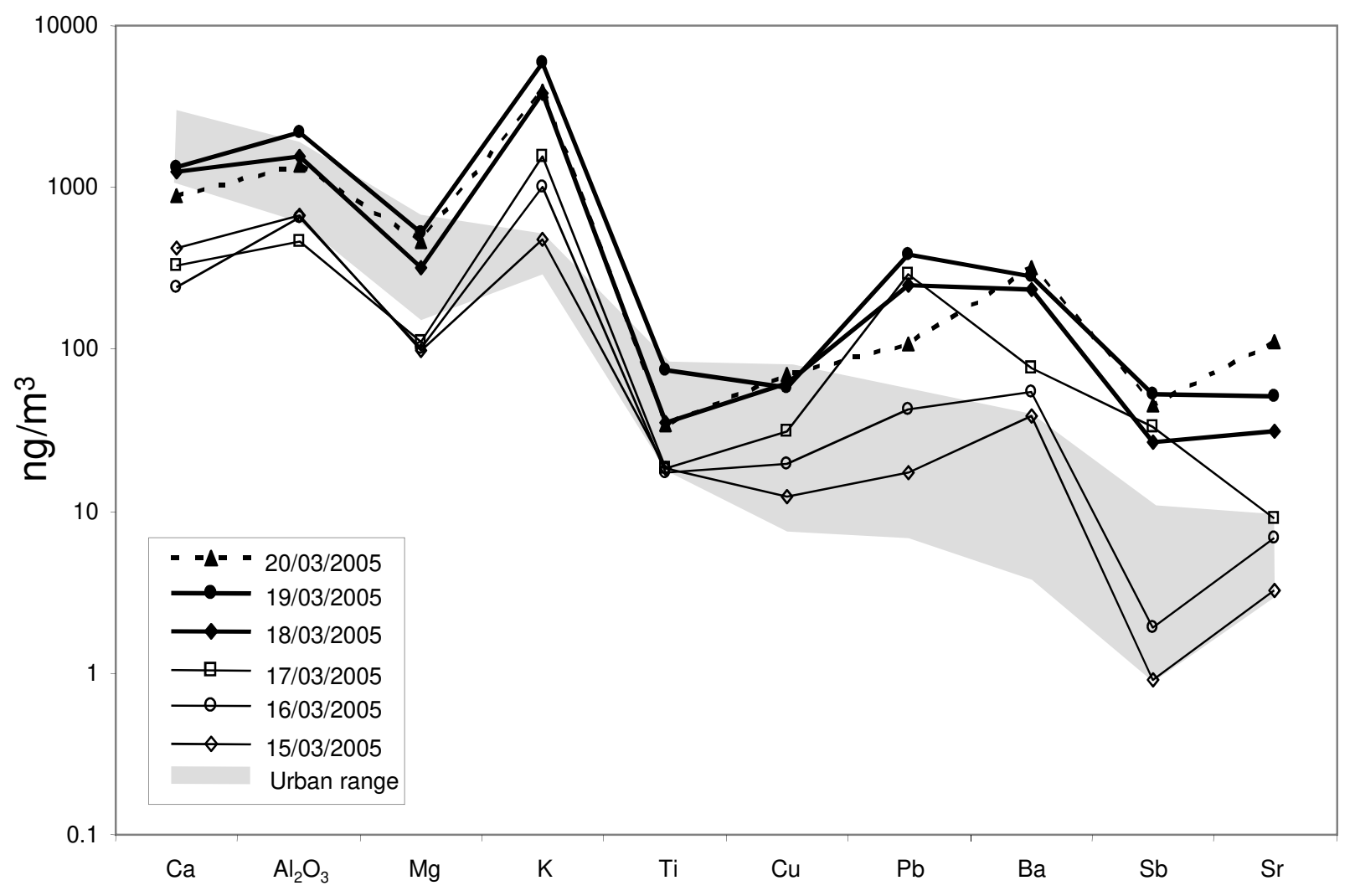

Fig 4 


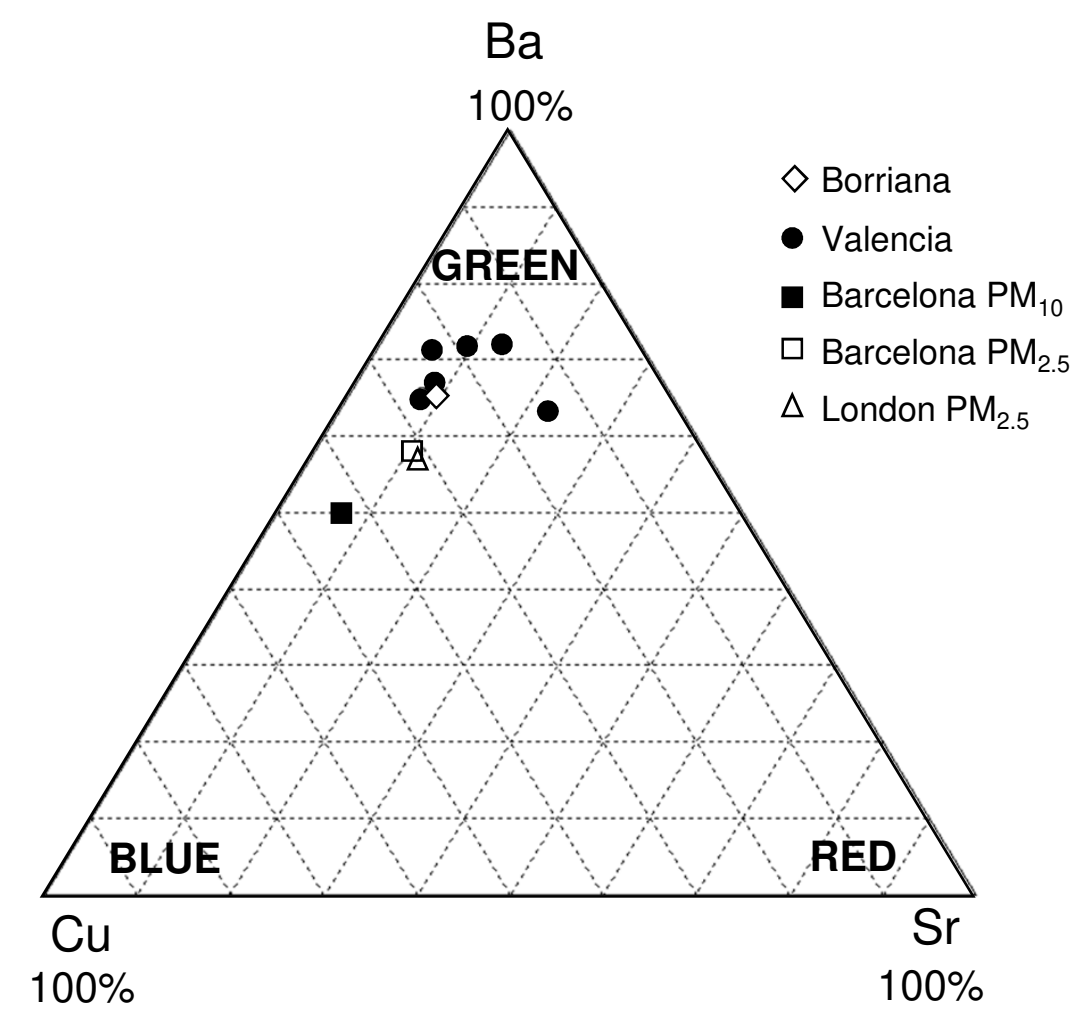

Fig 5 


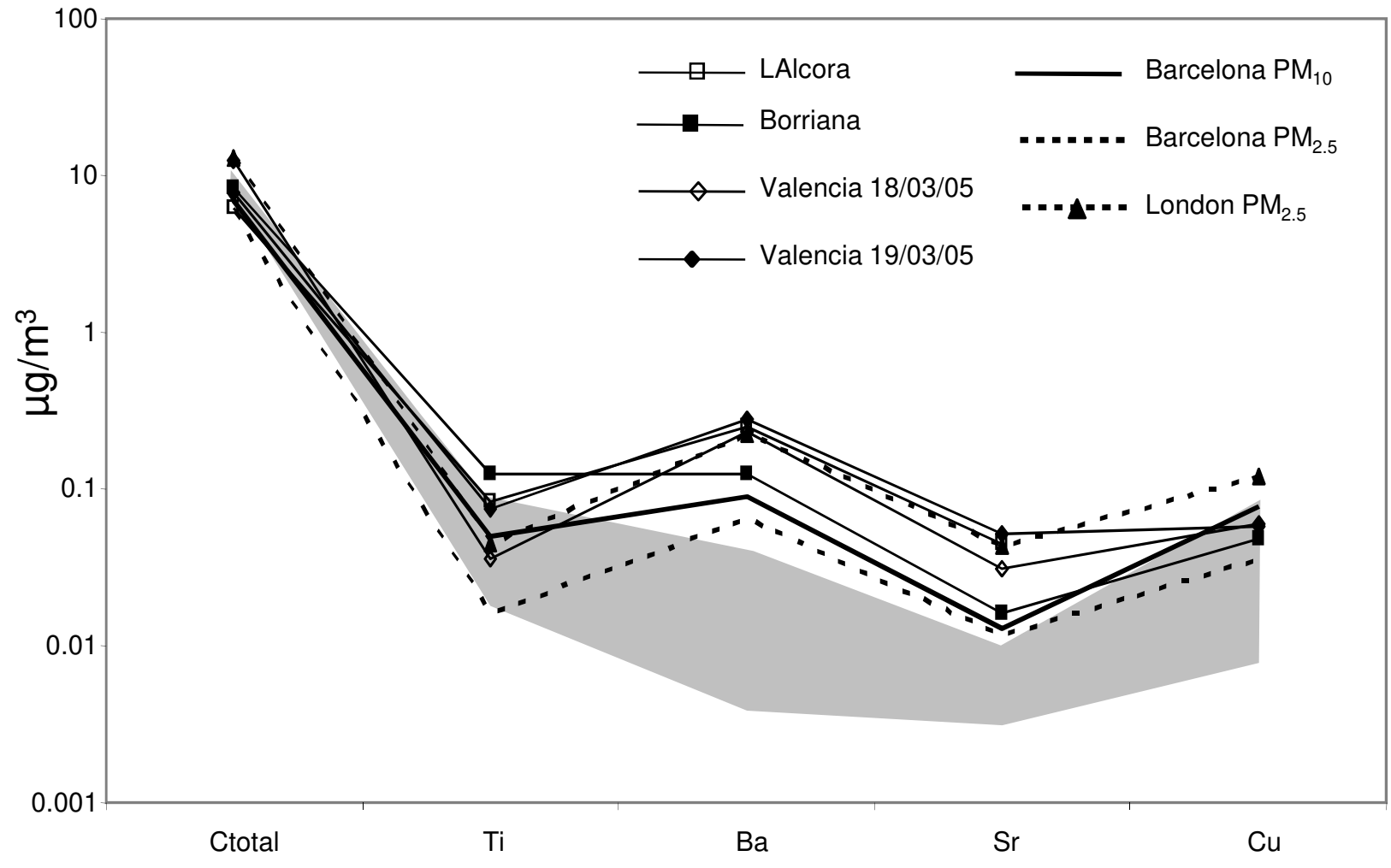

Fig 6 